\title{
PELAKSANAAN INOVASI PEMERINTAH DAERAH DALAM MEMOTIVASI APARATUR TERHADAP PENINGKATAN KUALITAS PELAYANAN PUBLIK DI KABUPATEN SUMEDANG PROVINSI JAWA BARAT
}

Oleh

\author{
Dadang Supriatna
}

Institut Pemerintahan Dalam Negeri

dadangsupriatna892@gmail.com

\begin{abstract}
$P$ ublic service is the most visible benchmark of government performance. The public can judge directly the performance of the government based on the services it receives. For this reason, the quality of public services in all ministries/institutions is a fundamental thing that must be improved immediately. Improving public services, the Ministry of Administrative Reform and Bureaucratic Reform (KemenPAN-RB) has implemented a policy that since 2014 has been a year of public service innovation. All government agencies, both at central and regional levels, are expected to be able to come up with creative ideas or answers to the workings/methods of public services. KemenPAN$R B$ collects and evaluates innovations that have been made in a number of agencies throughout Indonesia, so that they can continue to compete in a healthy manner with other agencies.

Law No. 25 of 2009 concerning public services, improving the quality of public services is an effort that must be carried out continuously, continuously and must be carried out by all government officials to innovate in order to meet the expectations of the community, thus the Regional Government needs to motivate employees in carrying out work in order to high enthusiasm so that innovation will arise in him, indirectly open his mind and mind or knowledge so that employees are high-performance and productive. To motivate employees, organizational leaders must know the motives and motivations desired by employees. So that the realization of quality public services which is one of the characteristics of good governance as the goal of the utilization of the State apparatus.

Based on the compiler's observations during the research at the Sumedang District Government, apparently there were still some indications of problems that showed that the quality of public services was still low. This can be seen from the indicators: 1) Inadequate work facilities, so that the services provided by employees to the public seem slow. 2) There are still employees who are not professional in handling jobs so there are still some jobs that do not finish on time. 3) There are some employees who are not friendly towards the community.
\end{abstract}

The problem is suspected because the Regional Government in the implementation of its motivation is not optimal. This is indicated as follows: 1) It is suspected that the Regional Government does not give awards to outstanding employees. 2) It is suspected that the Regional Government in delegating authority does not provide gui dan ce to employees so that there are still employees who have not been able to complete their tasks properly. 3) It is suspected that the Regional Government in giving reciprocal attention to the employees is still not good. In this study the authors used the descriptive analysis method. Data collection techniques used were literature study and field studies through observation, interviews and questionnaires. 
Questionnaire data were analyzed through qualitative analysis, ie data obtained in the field were analyzed, then conclusions were drawn and in the discussion using qualitative analysis techniques using percentages.

The results show that the average number of motivational implementation is $64 \%$ and if it is connected with data analysis criteria, it has just reached the title of Enough, so that it will affect the efforts to improve the quality of public services. While the level of public service quality has only reached an average of $63 \%$ and when linked to data analysis criteria, it has only reached the title of Fair.

Keywords: innovation, motivation, public service

\begin{abstract}
Abstrak
$\mathrm{P}$ elayanan publik merupakan suatu tolok ukur kinerja pemerintah yang paling kasat mata. masyarakat dapat menilai langsung kinerja pemerintah berdasarkan pelayanan yang diterimanya. Untuk itu kualitas pelayanan publik di semua kementerian/lembaga adalah suatu hal yang mendasar yang harus segera ditingkatkan. Peningkatan pelayanan publik, Kementerian Pendaya gunaan Aparatur Negara dan Reformasi Birokrasi (KemenPAN-RB) menerapkan kebijakan bahwa sejak 2014 adalah tahun inovasi pelayanan publik. Seluruh instansi pemerintah, baik di pusat maupun daerah diharapkan dapat membuat suatu ide kreatif atau jawaban terhadap cara kerja/metode pelayanan publik. KemenPAN-RB mengumpulkan dan menilai inovasi-inovasi yang telah dilakukan di sejumlah instansi di seluruh Indonesia, sehingga bisa terus bersaing secara sehat dengan instansi-instansi lain.
\end{abstract}

Undang-Undang No. 25 Tahun 2009 tentang pelayanan publik maka peningkatan kualitas pelayanan publik merupakan suatu upaya yang harus dilakukan secara terus menerus, berkelanjutan dan harus dilaksanakan oleh semua para aparatur pemerintah untuk berinovasi dalam rangka memenuhi harapan masyarakat, dengan demikian pemerintah daerah perlu memotivasi pegawai dalam melaksanakan pekerjaan agar mempunyai semangat tinggi sehingga akan timbul inovasi dalam dirinya, secara tidak langsung membuka akal dan pikiran atau ilmu pengetahuannya sehingga pegawai berkinerja tinggi dan produktif. Untuk memotivasi pegawai, pimpinan organisasi harus mengetahui motif dan motivasi yang diinginkan oleh para pegawai, sehingga terwujudnya pelayanan publik yang ber kualitas yang merupakan salah satu ciri dari pemerintahan yang baik sebagai tujuan dari pendaya gunaan aparatur negara.

Berdasarkan pengamatan penulis selama penelitian pada pemerintah daerah Kabupaten Sumedang, ternyata masih ditemui beberapa indikasi masalah yang menunjukkan bahwa kualitas pelayanan publik masih rendah. Hal ini terlihat dari indikator: 1) Fasilitas kerja yang kurang memadai, sehingga pelayanan yang diberikan pegawai kepada masyarakat terkesan lamban. 2) masih adanya pegawai yang belum profesional dalam menangani pekerjaan sehingga masih ada beberapa pekerjaan yang tidak selesai tepat waktu. 3) Ada sebagian pegawai yang bersikap kurang ramah terhadap masyarakat.

Permasalahan tersebut diduga karena pemerintah daerah dalam pelaksanaan motivasinya belum optimal. Hal ini diindikasikan sebagai berikut. 1) Diduga pemerintah daerah kurang memberi penghargaan kepada pegawai yang berprestasi. 2) Diduga pemerintah daerah dalam pendelegasian wewenang kurang memberikan bimbingan kepada pegawai sehingga masih ada pegawai yang belum bisa menyelesaikan tugas dengan baik. 3) Diduga pemerintah daerah dalam memberikan perhatian timbal balik kepada para pegawai masih kurang baik.

Dalam penelitian ini digunakan metode deskriptif analisis. Teknik pengumpulan data yang digunakan adalah studi Kepustakaan dan studi lapangan melalui observasi, wawancara dan angket. Data hasil angket dianalisis melalui analisis kualitatif, yaitu data-data yang diperoleh di lapangan dianalisis kemudian ditarik simpulan dan dalam pembahasannya menggunakan teknik analisis kualitatif dengan menggunakan persentase. 
Hasil menunjukkan bahwa angka rata-rata pelaksanaan motivasi, yaitu 64\% dan apabila dihubungkan dengan kriteria analisis data maka baru mencapai predikat Cukup, sehingga akan berpengaruh terhadap upaya meningkatkan kualitas pelayanan publik. Sementara tingkat kualitas pelayanan publik baru mencapai rata-rata 63\% dan apabila dihubungkan dengan kriteria analisis data maka baru mencapai predikat cukup.

Kata kunci: inovasi, motivasi, pelayanan publik

\section{PENDAHULUAN}

P elaksanaan otonomi daerah sangat bergantung pada kesiapan pemerintah daerah dalam menata sistem pemerintahannya agar tercipta pelayanan publik yang efektif, efisien, transparansi dan akuntabel serta mendapat partisipasi masyarakat dalam penyelenggaraan pemerintahannya.

Konsekuensi dari pelaksanaan Otonomi Daerah setelah ditetapkannya UndangUndang No. 23 Tahun 2014 tentang Pemerintahan Daerah, di mana pemerintah daerah diberi kewenangan yang luas oleh pemerintah pusat untuk mengatur rumah tangga daerahnya sendiri, termasuk dalam memberikan pelayanan kepada masyarakat di daerahnya.

Penerapan kebijakan otonomi daerah sangat penting untuk meningkatkan kualitas pelayanan publik, dengan hal ini pemerintah daerah menerapkan Undang-Undang No. 25 Tahun 2009 tentang pelayanan publik sebagai upaya pemerintah daerah dalam meningkatkan kualitas pelayanan publik yang merupakan sesuatu harus dilakukan secara terus menerus, berkelanjutan dan harus dilaksanakan oleh semua para aparatur pemerintah.

Inovasi pelayanan publik pemerintah daerah Kabupaten Sumedang Provinsi Jawa Barat saat ini menjadi pembicaraan masyarakat luas, khususnya di Kabupaten Sumedang, dalam mewujudkan pelayanan yang berkualitas kepada masyarakat. sebagai wujud perhatian pemerintah daerah Sumedang untuk memenuhi harapan dan keinginan masyarakat terhadap efektivitas penyelenggaraan pelayanan publik, maka pemerintah daerah Kabupaten Sumedang membentuk wadah pelayanan publik yang saat ini dipopulerkan dengan nama "Mall pelayanan".

Pelayanan publik adalah pelayanan yang wajib diselenggarakan negara untuk pemenuhan kebutuhan dasar atau hak-hak dasar warga negara (publik). Pembukaan UUD 1945 mengamanatkan hal tersebut. Ketiadaan atau kurang memadainya pelayanan publik akan mengakibatkan tidak terpenuhinya hak asasi manusia oleh penyelenggara negara. pelayanan publik harus diberikan pada setiap warga negara, baik yang kaya maupun miskin, baik yang berada di pusat kemajuan maupun daerah terbelakang, baik yang mendatangkan keuntungan atau membutuhkan subsidi. karena itu negara harus mengambil peranan dan tanggung jawab dalam penyelenggaraan pelayanan publik.

Setiap warga negara berhak mendapat pelayanan publik yang ber kualitas dari pemerintah yang wajib melindungi setiap warga negaranya dan memastikan bahwa mereka telah mendapat pelayanan publik dengan layak. Hal ini, pemerintah perlu mengatur hubungan antara warga negara sebagai konsumen pelayanan publik dengan penyelenggara pelayanan publik untuk memperoleh hak-haknya.

Salah satu tugas pemerintah daerah adalah memberikan pelayanan kepada masyarakat yang mendukung terlaksananya pembangunan yang merata di segala bidang di setiap wilayahnya sehingga tercipta masyarakat yang adil, makmur, dan sejahtera. Mengingat begitu luasnya wilayah negara serta semakin meningkatnya pembangunan dan semakin luasnya persoalan yang dihadapi 
oleh pemerintah, maka untuk memungkin kan terselenggaranya pembangunan dan administrasi pemerintahan secara efektif dan merata, pemerintah telah mem bagi wilayahnya dalam berbagai tingkatan. Untuk memenuhi hal tersebut, maka pemerintah harus lebih responsif dan akuntabel guna memberikan pelayanan prima dan dapat memuaskan masyarakat, dengan demikian pelayanan publik dapat ditafsirkan sebagai tanggung jawab pemerintah atas kegiatan yang ditujukan untuk kepentingan umum dan masyarakat yang mengandung adanya unsur-unsur perhatian dan kesediaan serta kesiapan dari pelaksanaan pelayanan tersebut.

Aparat pemerintah tentunya lebih meningkatkan keterampilan atau keahlian dan semangat yang tinggi sebagai pelayan publik, sehingga pelayanan dapat secara maksimal diterima dan memberikan kepuasan bagi masyarakat. pemerintah daerah Kabupaten Sumedang yang sesuai dengan tugas pokoknya dalam menyelenggarakan pemerintahannya, pembinaan pemerintah desa, serta pembinaan kemasyarakatan, maka dituntut adanya pegawai yang mampu melaksanakan tugasnya dengan baik, sehingga tujuan organisasi dapat tercapai secara maksimal. Terkait dengan unsur pelaksana, organisasi pemerintah daerah beserta seluruh anggotanya merupakan bagian organisasi dalam lingkungan pemerintahnya Kabupaten Sumedang mempunyai peranan yang penting dalam penyelenggaraan tugas pemerintahan dan pembangunan di wilayahnya. maka hal ini, diperlukan upaya peningkatan kualitas pegawai dalam melaksanakan tugas pemberian pelayanan publik yang baik kepada masyarakat.

Kondisi pelayanan publik di pemerintah daerah sejauh ini masih rendah, hal tersebut terlihat dari indikator sebagai berikut.

1. Fasilitas kerja yang kurang memadai, sehingga menghambat dalam penyelesaian pekerjaan.
2. Masih adanya perbedaan individu pegawai di dalam pelaksanaan pemberian pelayanan kepada masyarakat karena perbedaan keahlian/ kemampuan pegawai.

Berdasarkan beberapa permasalahan yang penulis temukan dalam observasi tersebut, maka penulis mengasumsikan bahwa pegawai pada pemerintah daerah Kabupaten Sumedang belum sepenuhnya dapat menjalankan tugas pekerjaannya dengan baik, sehingga akan berpengaruh terhadap pelayanan publik yang diberikan kepada masyarakat. Satu hal yang penulis asumsikan kemudian sebagai faktor yang menyebabkan rendahnya pelayanan publik pada pemerintah daerah Kabupaten Sumedang tersebut adalah faktor motivasi kerja, hal ini dilihat dari indikator sebagai berikut.

1. Kurangnya pemerintah daerah memberikan penghargaan kepada pegawai yang berprestasi.

2. Kurangnya memberi bimbingan dalam pendelegasian wewenang oleh pemerintah daerah kepada pegawai sehingga masih ada pegawai yang belum bias menyelesaikan tugas dengan baik.

3. Masih kurangnya perhatian pemerintah daerah kepada para pegawai sehingga timbal balik tidak berjalan dengan baik.

\section{Rumusan Masalah}

Untuk memudahkan dalam penelitian dan pembahasan yang akan dilakukan, maka penulis merumuskan masalah tersebut di atas sebagai berikut.

1. Bagaimana pelaksanaan inovasi pemerintah daerah dalam memotivasi aparatur terhadap peningkatan kualitas pelayanan publik di Kabupaten Sumedang?

2. Faktor-faktor apakah yang menjadi penghambat pelaksanaan inovasi pemerintah daerah dalam memotivasi aparatur terhadap peningkatan 
kualitas pelayanan publik di Kabupaten Sumedang?

3. Usaha-usaha apa saja yang dilakukan oleh pemerintah daerah untukmengatasi hambatan-hambatan tersebut?

\section{Tujuan Penelitian}

Penelitian yang dilakukan penulis bertujuan sebagai berikut.

1. Untuk mengetahui bagaimana pelaksanaan oleh pemerintah daerah dalam memotivasi aparatur upaya meningkatkan pelayanan publik.

2. Untuk mengetahui faktor penghambat yang dihadapi oleh pemerintah daerah dalam pelaksanaan inovasi pemerintah daerah dalam memotivasi aparatur terhadap peningkatan kualitas pelayanan publik di Kabupaten Sumedang.

3. Untuk mengetahui usaha-usaha apa yang dilakukan oleh pemerintah daerah untuk mengatasi hambatan-hambatan tersebut.

\section{TINJAUAN PUSTAKA}

\section{Inovasi}

Inovasi dalam hal ini merupakan suatu gagasan dari pemegang kekuasaan dalam rangka meningkatkan kualitas dan integritas lembaga untuk pencapaian tujuan organisasi.

Kabupaten Sumedang merupakan pemerintah daerah yang ber keinginan tinggi dalam meningkatkan kualitas pelayanan publik yang diharapkan oleh masyarakat seluruh wilayah di Kabupaten Sumedang, dengan hal ini pemerintah daerah Kabupaten Sumedang mempunyai suatu gagasan untuk menunjang dengan mendirikan mall pelayanan publik. Mall pelayanan publik ini diharapkan dapat memenuhi harapan publik secara adil dan merata.

Menurut Rina Mei Mirnasari (2013) mengartikan inovasi, yaitu sebagai prestasi dalam meraih, meningkatkan, dan memperbaiki efektivitas, efisiensi dan akuntabilitas pelayanan publik yang dihasilkan oleh inisiatif pendekatan, metodologi, dan atau alat baru dalam pelayanan masyarakat.

Pendapat Lu \& Tseng (2010) inovasi adalah suatu proses yang berisi konsepkonsep baru dan produksi, pengembangan dan implementasi perilaku. ini juga merupakan metode, perubahan respons terhadap lingkungan eksternal atau tindakan pertama akibat pengaruh lingkungan terhadap transformasi organisasi.

Dari uraian di atas, dapat disimpulkan bahwa dalam menjalankan inovasi pemerintahannya, seorang pimpinan atau kepala daerah hendaknya:

a. Memperhatikan dan memahami bawahan dalam melaksanakan tugas dan fungsinya sesuai arahan pimpinan.

b. Mempertimbangkan, mengawasi dan membina serta mengarahkan pegawai dalam pelaksanaan inovasi pemerintah daerah.

c. Tugas pemerintah daerah dalam pelaksanaan inovasi pelayanan publik yang ber kualitas selalu diharapkan oleh masyarakat, dalam hal ini pemerintah daerah sangat penting untuk meningkatkan kualitas sumber daya manusia dalam rangka terwujudnya tujuan organisasi.

\section{Motivasi}

Peranan pegawai sangat penting sekali pada setiap organisasi pemerintah sebagai unsuryang paling dominan dalam pencapaian tujuan organisasi. Oleh karenanya seorang pimpinan sudah selayaknya memberikan perhatian terhadap pegawai dan memotivasi agar setiap pegawai mau bekerja dengan semangat dan keikhlasan.

Motivasi secara harfiah bermakna kegiatan pimpinan untuk mendorong orangorang untuk mau bergerak atau bekerja. Oleh karena itu, motivasi selalu berhubungan 
dengan manusia. Dalam melaksanakan fungsi motivasi, seorang pimpinan dituntut memiliki kemampuan untuk dapat mengarahkan tenaga, semangat dan dapat memberikan bimbingan terhadap para pegawai untuk mencapai tujuan organisasi yang telah ditetapkan. Dengan demikian diharapkan akan dapat berpengaruh pada peningkatan kualitas kerja pegawai dalam memberikan pelayanan terhadap masyarakat.

Untuk lebih memperjelas pemahaman mengenai pengertian motivasi, akan penulis kemukakan pendapat beberapa ahli di antaranya Sondang P. Siagian (2004: 138) dalam bukunya Teori Motivasi dan Aplikasinya mengemukakan pengertian motivasi sebagai berikut.

"Motivasi adalah daya pendorong yang mengakibatkan seseorang anggota organisasi mau dan rela untuk mengarahkan kemampuan dalam bentuk keahlian atau keterampilan tenaga dan waktunya untuk menyelenggarakan berbagai kegiatan yang menjadi tanggung jawabnya dan menunaikan kewajibannya, dalam rangka pencapaian tujuan dan berbagai sasaran organisasi yang telah ditentukan sebelumnya".

Pendapat Ambar Teguh Sulistiyani dan Rosidah (2009: 76) dalam buku Manajemen $S D M$, menyatakan bahwa:

"Motivasi merupakan proses pemberian dorongan kepada anak buah supaya anak buah dapat bekerja sejalan dengan batasan yang diberikan guna mencapai tujuan organisasi secara optimal, pengertian proses pemberian dorongan tersebut adalah serangkaian aktivitas yang harus dilalui atau dilakukan untuk menumbuhkan dorongan kepada pegawai untuk bekerja sejalan dengan tujuan organisasi".

Menurut Miftah Thoha (2001: 181) dalam bukunya Perilaku Organisasi Konsep Dasar dan Aplikasi, mengartikan motivasi sebagai berikut.
Motivasi adalah sebagai dorongan yang menyebabkan mengapa seseorang itu berusaha mencapai tujuan-tujuan, baik sadar atau tidak sadar. Dorongan itu pula yang menyebabkan seseorang itu berperilaku, yang dapat mengendalikan dan memelihara kegiatan-kegiatan, dan yang menetapkan arah umum.

Menurut Siswanto Sastrohadiwiryo (2001: 267) dalam bukunya Manajemen Tenaga Kerja Indonesia berpendapat:

"Motivasi dapat diartikan sebagai keadaan kejiwaan dan sikap mental manusia yang memberikan energi, mendorong kegiatan atau menggerakkan dan mengarahkan atau menyalurkan perilaku ke arah mencapai kebutuhan yang memberi kepuasan atau mengurangi ketidakseimbangan".

Berdasarkan beberapa pendapat di atas tentang motivasi dapat disimpulkan bahwa pengertian motivasi adalah memberi dorongan sebagai salah satu upaya untuk menumbuhkan semangat dan gairah kerja para pegawai dengan segala potensi yang dimilikinya.

Dari uraian di atas, dapat ditaris simpulan bahwa dalam menjalankan motivasi terhadap bawahannya, seorang pimpinan hendaknya:

a. Mengamati dan memahami perilaku bawahan.

b. Mempertimbangkan, mengawasi dan mengubah serta mengarahkan tingkah laku bawahannya.

c. Tugas pimpinan dalam mengarahkan perilaku bawahannya bertujuan agar perilaku mereka tidak bertentangan dengan norma, peraturan serta tujuan organisasi tersebut.

\section{Asas-Asas motivasi}

Tercapainya suatu tujuan yang berhasil guna, maka selaku pucuk pimpinan harus memperhatikan beberapa pedoman, 
sehingga dapat mengarah kepada tercapainya tujuan bersama. Tujuan dapat tercapai bilamana seorang pemimpin dapat menerapkan motivasi dengan baik dan mampu menerapkan asas-asas motivasi secara optimal.

Adapun asas-asas motivasi yang digunakan, menurut Malayu S. P. Hasibuan (2006: 221) dalam bukunya Manajemen Dasar, Pengertian, dan Masalah", mengemukakan bahwa asas-asas motivasi, yaitu sebagai berikut.

1. Asas mengikutsertakan.

2. Asas komunikasi.

3. Asas pengakuan.

4. Asas wewenang yang didelegasikan.

5. Asas adil dan layak.

6. Asas perhatian timbal balik.

Untuk lebih jelasnya mengenai asas-asas motivasi tersebut di atas, maka penulis akan mencoba menguraikan satu persatu dari asas-asas motivasi tersebut, yaitu sebagai berikut.

\section{Asas Mengikutsertakan}

Seorang pimpinan organisasi harus senantiasa memberikan kesempatan kepada pegawainya atau bawahannya untuk mengambil suatu keputusan yang berkaitan dengan bidang tugasnya, serta memperhatikan setiap saran maupun kritik yang disampaikan oleh para pegawai, sehingga pegawai merasa dihargai serta terdorong untuk berusaha mencapai tujuan organisasi, sebagai hasil dari keputusan yang diambilnya.

2. Asas Komunikasi

Setiap informasi tentang tujuan yang hendak dicapai oleh organisasi, harus selalu disampaikan oleh seorang pimpinan, baik mengenai cara-cara mengerjakannya maupun kendalakendala yang dihadapi, sehingga para pegawai merasa tertantang untuk senantiasa berpegang kepada informasi yang telah disampaikan oleh pimpinan, untuk mengefektifkan penyampaian informasi tersebut, dalam arti dipahami tentang isi serta tujuannya, maka penyampaiannya harus menggunakan bahasa yang mudah dimengerti oleh para pegawai sehingga para pegawai benar-benar dapat memahami informasi tersebut.

3. Asas Pengakuan

Terhadap pegawai yang berprestasi hendaknya pimpinan organisasi harus berusaha untuk memberikan penghargaan yang tepat dan wajar, sehingga pegawai tersebut merasa terdorong untuk lebih meningkatkan lagi prestasi kerjanya dan bagi pegawai yang lainnya merupakan suatu dorongan agar mengikuti jejak pegawai yang sudah mendapat kan penghargaan tersebut.

4. Asas Wewenang yang Didelegasikan

Dalam pencapaian tujuan organisasi, hendaknya seorang pimpinan senantiasa melakukan pendelegasian sebagian wewenang kepada pegawai sehingga para pegawai diberi kepercayaan, yang pada akhirnya akan memotivasi semangat kerjanya, namun di dalam pendelegasian wewenang tersebut hendaknya pimpinan organisasi berusaha meyakinkan pegawainya bahwa mereka mampu dan bisa melaksanakannya dan menekankan suatu pertanggungjawaban di dalam pelaksanaan wewenang tersebut.

Pendelegasian wewenang akan efektif apabila diberikan kepada petugas yang tepat dalam arti dalam pemberian wewenang harus sesuai dengan ke mampu an dan keterampilan yang sesuai dengan kompetensi di bidang tugasnya.

5. Asas Adil dan Layak

Sebagai pimpinan organisasi harus mampu memberikan alat dan jenis motivasi sesuai dengan asas keadilan dan kelayakan terhadap semua pegawai. 
Dalam pemberian hadiah atau hukuman terhadap semua pegawai hendaknya pimpinan harus adil dan layak apabila masalahnya sama. Hal tersebut guna untuk meningkatkan disiplin kerja pegawai.

6. Asas Perhatian Timbal Balik

Pimpinan organisasi harus berusaha mengemukakan keinginan atau harapan yang hendak dicapai oleh organisasi melalui pelaksanaan pekerjaan oleh para pegawai, sehingga mereka merasa terdorong untuk memenuhinya dengan ikhlas dan setelah terpenuhinya harapan tersebut, maka seorang pimpinan organisasi harus memperhatikan kebutuhan-kebutuhan para pegawai sebagai kompensasi atau wujud nyata timbal balik antara organisasi dengan pegawainya, di antaranya memperhatikan kebutuhan akan fasilitas kerja, mewujudkan suasana kerja yang menyenangkan serta memberikan kesempatan pada pegawai untuk mengaktualisasikan diri.

Apabila memperhatikan uraian-uraian di atas tentang pelaksanaan motivasi seperti tersebut di atas, maka dapat ditarik suatu simpulan bahwa seorang pimpinan organisasi di dalam pelaksanaan motivasinya harus memperhatikan asas-asas motivasi.

\section{Kualitas Pelayanan Publik}

Sebelum menguraikan pengertian kualitas pelayanan publik, terlebih dahulu akan dikemukakan pengertian dari kualitas, sebagaimana dikemukakan oleh beberapa ahli di bawah ini.

Kata kualitas memiliki banyak definisi yang berbeda dan bervariasi dari yang konvensional sampai yang lebih sategis. Vincent Gaspersz (2001: 175) yang dikutip Teguh Yuwono dalam buku Manajemen Otonomi Daerah mengemukakan definisi konvensional bahwa :
"Kualitas biasanya menggambarkan karakteristik langsung dari suatu produk misalnya performa (performance), keandalan (reability), mudah dalam penggunaan dan sebagainya".

Lebih lanjut ia menjelaskan definisi strategic kualitas sebagai sesuatu yang mampu memenuhi keinginan atau kebutuhan pelanggan. Sementara itu, Sinambela (2006: 6) dalam bukunya yang berjudul Reformasi Pelayanan Publik, mendefinisikan kualitas adalah segala sesuatu yang mampu memenuhi keinginan atau kebutuhan pelanggan. kualitas pelayanan merupakan tingkat keunggulan yang diharapkan dan pengendalian atas tingkat keunggulan tersebut untuk memenuhi harapan pelanggan.

Berdasarkan penjelasan tersebut, kualitas dapat diartikan sebagai kinerja profesional, yang berorientasi terhadap pemenuhan dan kebutuhan masyarakat atas hak dasar dalam pelayanan.

\section{Pelayanan Publik}

Pelayanan pada dasarnya adalah cara melayani, membantu, menyikapi, mengurus, menyelesaikan keperluan kebutuhan seseorang atau sekelompok orang dan kegiatan pelayanan pada dasarnya menyangkut pemenuhan suatu hak. Seperti yang dilaksanakan pada instansi pemerintah di pusat, daerah, dan lingkungan Badan Usaha Milik Negara (BUMN), Badan Usaha Milik Daerah dalam bentuk barang dan jasa baik dalam rangka upaya pemenuhan kebutuhan masyarakat maupun dalam rangka pelaksanaan ketentuan perundangundangan. Seperti yang dikemukakan oleh Harbani Pasolong (2008: 198) dalam bukunya Kepemimpinan Birokrasi menjelaskan pelayanan adalah aktivitas seseorang, kelompok dan atau organisasi baik langsung maupun tidak langsung untuk memenuhi kebutuhan.

Pengertian pelayanan juga dikemukakan 
oleh Paimin Napitupulu (2007: 164) dalam bukunya yang berjudul Pelayanan Publik dan Customer Satisfaction mengartikan pelayanan sebagai berikut.

"Serangkaian kegiatan atau proses pemenuhan kebutuhan orang lain secara lebih memuaskan berupa produk jasa dengan sejumlah ciri seperti tidak berwujud, cepat hilang, lebih dapat dirasakan dari pada memiliki, dan pelanggan lebih dapat berpartisipasi aktif dalam proses mengonsumsi jasa tersebut."

Pengertian pelayanan publik menurut Agus Dwiyanto (2008: 136) dalam bukunya Mewujudkan Good Governance melalui Pelayanan Publik mendefinisikan pelayanan publik adalah:

"Serangkaian aktivitas yang dilakukan oleh birokrasi publik untuk memenuhi kebutuhan warga pengguna. Pengguna yang dimaksud di sini adalah warga negara yang membutuhkan pelayanan publik, seperti pembuatan kartu tanda penduduk (KTP), akta kelahiran, akta nikah, akta kematian, sertifikat tanah, izin usaha, izin mendirikan bangunan (IMB), izin gangguan (HO), izin pengambilan air tanah, berlangganan air minum, listrik dan sebagainya".

Pengertian pelayananpublikberdasarkan Keputusan Menteri Pendayagunaan Aparatur Negara No. 63 Tahun 2003 adalah segala kegiatan pelayanan yang dilaksanakan oleh penyelenggara pelayanan publik sebagai upaya pemenuhan kebutuhan penerima pelayanan maupun pelaksanaan ketentuan peraturan perundang-undangan.

Berdasarkan penjelasan di atas, maka pelayanan publik harus selalu berubah mengikuti perkembangan masyarakat, karena masyarakat itu bersifat dinamis. Dalam hal ini pemerintah harus melakukan negosiasi dan mengolaborasi berbagai kepentingan masyarakat, sehingga pelayanan publik memiliki kualitas yang sesuai dengan yang diharapkan masyarakat.

\section{Kriteria Kualitas Pelayanan}

Dalam suatu organisasi yang bertujuan memberikan pelayanan untuk dapat unggul bersaing adalah memberikan pelayanan dengan kualitas yang lebih tinggi dari pesaingnya secara konsisten. Untuk dapat menilai sejauh mana kualitas pelayanan publik yang diberikan oleh aparatur pemerintah, perlu ada kriteria yang menunjukkan apakah suatu pelayanan publik yang diberikan dapat dikatakan baik atau buruk.

Menurut Zeithaml-Parasurman-Berry yang dikutip Harbani Pasolong dalam buku Teori Administrasi Publik (2011: 135), mengemukakan dalam mendukung hal tersebut, ada lima dimensi yang harus diperhatikan dalam melihat tolak ukur kualitas pelayan publik, yaitu sebagai berikut.

1. Tangibles (wujud fisik) adalah kualitas pelayanan berupa sarana fisik perkantoran, komputerisasi administrasi, ruang tunggu, tempat informasi.

Tangibles berupa sarana dan prasarana, ruang kerja serta fasilitas yang memadai. Ruang kerja yang baik dalam arti memenuhi kriteria ventilasi, tata cahaya, kebersihan, kerapihan dan keindahan, sehingga akan membuat penghuninya merasa nyaman berada di dalamnya. di samping itu wajib menyediakan fasilitas yang mendukung pelayanan yang efektif, seperti ruang tunggu, tempat informasi dan fasilitas lainnya untuk pengembangan aspek-aspek kepribadian.

2. Reliability (kehandalan) adalah kemampuan dan keandalan untuk menyediakan pelayanan yang terpercaya.

Reliability merupakan kemampuan aparatur pemerintah untuk menyelenggarakan pelayanan publik yang dijanjikan secara akurat. Baik kemampuan sumber daya manusia, serta realisasi program yang telah ditetapkan untuk meningkatkan mutu pelayanan. 
3. Resfonsives (tanggap) adalah kesanggupan untuk membantu dan menyediakan pelayanan secara cepat dan tepat, serta tanggap terhadap keinginan konsumen.

Responsive merupakan kemampuan dari aparatur pemerintah agar selalu tanggap terhadap berbagai aspirasi yang muncul bagi peningkatan mutu. karena itu aparatur pemerintah harus selalu membaca lingkungan dan menanggapinya secara cepat dan tepat, bahkan aparatur pemerintah tidak hanya mampu menyesuaikan terhadap perubahan/tuntutan, akan tetapi mampu mengantisipasi hal-hal yang mungkin terjadi. Dengan demikian organisasi dapat meningkatkan kualitas pelayanan kepada masyarakat, selalu berfokus kepada pencapaian layanan, sehingga pelayanan yang diberikan untuk memenuhi keinginan masyarakat. menerapkan prinsip menyiapkan kualitas pelayanan sebaik mungkin, perlu dilakukan untuk dapat meningkat, di mana yang penting untuk dilakukan adalah memberikan pelayanan yang dijanjikan secara tepat dan memiliki rasa tanggung jawab terhadap mutu pelayanan.

4. Assurance (jaminan) adalah kemampuan dan keramahan serta sopan santun pegawai dalam meyakinkan kepercayaan konsumen.

Assurance adalah dimensi dari kualitas pelayanan yang berkaitan dengan pengetahuan dan keramahan petugas pemberi layanan serta kemampuan mereka untuk menumbuhkan kepercayaan dan kenyamanan bagi pengguna layanan. Aspek ini salah satu yang paling diharapkan masyarakat.

Petugas yang ramah akan menjadi salah satu faktor pendukung bagi pengguna layanan untuk memberikan penilaian yang baik atas pelayanan yang diberikan.
5. Emphaty adalah sikap tegas tetapi penuh perhatian dari pegawai terhadap konsumen.

Emphaty merupakan kemampuan atau perhatian pihak aparatur pemerintah terhadap masyarakat, baik berupa tanggapan atas saran untuk perbaikan layanan publik, tanggapan atas keluhan, dan lain-lain.

\section{METODE PENELITIAN}

Dalam penelitian ini digunakan metode deskriptif analisis. Teknik pengumpulan data yang digunakan adalah studi Kepustakaan dan studi lapangan melalui observasi, wawancara dan angket. Data hasil angket dianalisis melalui analisis kualitatif, yaitu data-data yang diperoleh dari lapangan dianalisis kemudian ditarik simpulan dan dalam pembahasannya menggunakan teknik analisis kualitatif dengan menggunakan persentase.

\section{Jenis Data}

Jenis data terdiri dari jenis data primer dan data sekunder. Data primer adalah data yang dapat diperoleh langsung dari lapangan atau tempat penelitian dan data sekunder adalah data-data yang didapat dari sumber bacaan dan berbagai macam sumber lainnya yang terdiri dari surat-surat pribadi, buku harian, notula rapat perkumpulan, sampai dokumen-dokumen resmi dari berbagai instansi pemerintah.

Data sekunder juga dapat berupa majalah, buletin, publikasi dari berbagai organisasi, lampiran-lampiran dari badan-badan resmi seperti kementeriankementerian, hasil-hasil studi, hasil survei, studi historis, dan sebagainya.

\section{Teknik Pengumpulan Data}

Penelitian ini dilaksanakan dengan menggunakan metode deskriptif 
analisis, yaitu metode penelitian yang menggambarkan suatu keadaan atau fenomena secara faktual atau berdasarkan fakta-fakta atau kenyataan yang ada pada saat penelitian berlangsung, hasilnya dikumpulkan dan dipilih sesuai dengan kebutuhan penelitian, selanjutnya datahasil penelitian ini dianalisis lebih lanjut sebagai bahan menarik simpulan. Digunakan beberapa teknik pengumpulan data sebagai berikut.

1) Studi Kepustakaan, yaitumengumpulkan dan mempelajari bahan-bahan tertulis dengan tujuan untuk memahami konsep-konsep yang berkaitan dengan sasaran penelitian.

2) Studi Lapangan, dalam hal ini digunakan tiga cara:

a. Observasi, yaitu mengadakan pengamatan langsung terhadap objek penelitian tanpa melibatkan diri kepada kegiatan yang sedang berlangsung dengan maksud untuk mengetahui selengkap mungkin mengenai permasalahan yang terdapat dalam objek penelitian.

b. Wawancara, yaitu teknik pengumpulan data dengan cara bertanya langsung kepada responden.

c. Angket atau daftar pertanyaan, yaitu teknik pengumpulan data dengan cara menyebarkan daftar pertanyaan yang telah dipersiapkansebelumnya kepada responden.

\section{Analisis Data}

Teknik analisis data yang digunakan dalam penelitian ini adalah teknik modus, yaitu cara analisis dengan mengambil jawaban yang paling banyak. Teknik modus yang digunakan dalam penelitian ini berdasarkan pendapat Nurkancana, dengan menggunakan rumus sebagai berikut.
$\mathrm{P}=(f / n) \times 100 \%$

Keterangan:

$\mathrm{P}=$ Persentase jumlah responden yang member jawaban

$f=$ Frekuensi responden yang memberi jawaban

$n=$ Jumlah responden

\section{PEMBAHASAN}

\section{Pelaksanaan Inovasi Pemerintah Daerah dalam Memotivasi Aparatur}

Peranan pimpinan dalam suatu organisasi baik organisasi pemerintah maupun swasta yang besar maupun yang kecil sangat menentukan ke arah pencapaian tujuan. Seorang pimpinan harus mampu menggerakkan bawahannya agar mau dan mampu melaksanakan tugas dengan ikhlas sehingga apa yang menjadi tujuan organisasi dapat tercapai sesuai dengan rencana yang telah ditetapkan sebelumnya. Seperti yang telah dikemukakan sebelumnya bahwa motivasi merupakan salah satu unsur yang penting dalam suatu organisasi dalam rangka mendukung pelaksanaan inovasi pemerintah, sebab untuk melaksanakan berbagai tugas dan pekerjaan, diperlukan adanya suatu kegiatan yang dapat memberikan dorongan atau semangat kerja pegawai, sehingga dengan adanya upaya seperti itu dapat diharapkan tindakantindakan pegawai dalam melaksanakan tugas dan tanggung jawab yang dibebankan kepadanya dapat dilaksanakan dengan baik sesuai dengan tujuan yang diinginkan oleh organisasi tersebut.

Pada prinsipnya motivasi yang diberikan oleh seorang pimpinan kepada bawahan dengan tujuan agar dapat melaksanakan pekerjaan untuk menghasilkan pelayanan yang baik, hal ini sangat didambakan oleh seorang pimpinan dan sangat diharapkan oleh masyarakat sebagai pengguna jasa. Seorang pimpinan harus menempatkan 
dirinya di tengah-tengah para bawahannya atau seorang pimpinan di dalam melaksanakan motivasi berada di antara bawahannya dalam arti pimpinan dalam memberikan instruksi, nasihat, bimbingan, pengarahan, dan koreksi berada pada saat diperlukan, dengan demikian dapat dikatakan bahwa motivasi mempunyai peranan penting dalam penyelenggaraan suatu organisasi, serta dapat menentukan terhadap perilaku seseorang dalam melaksanakan kewajibannya terutama dalam upaya meningkatkan kualitas pelayanan publik (masyarakat).

Pemerintah daerah Kabupaten Sumedang selaku pucuk pimpinan dalam struktur organisasi pemerintahan daerah mempunyai peranan sangat penting serta menentukan sekali terhadap maju atau mundurnya pemerintahan di daerahnya, terutama dalam pencapaian tujuan yang telah ditentukan sebelumnya. Dalam hal ini seorang pimpinan dituntut untuk benarbenar berperan sebagai komando dalam menggerakkan para bawahannya sehingga mereka mau bekerja dengan ikhlas dan disertai rasa tanggung jawab yang tinggi dalam arti mampu melaksanakan tugas dan menyelesaikannya suatu pekerjaan yang dibebankan kepadanya tepat pada waktu yang telah ditentukan, dengan kata lain dalam melaksanakan tugas pegawai harus mampu memberikan pelayanan yang optimal kepada masyarakat sebagai pengguna jasa pada setiap saat memerlukannya.

Untuk menganalisis pelaksanaan inovasi pemerintah daerah memotivasi aparatur yang didasari oleh asas-asas motivasi sebagai dasar keberlangsungan inovasi, yaitu sebagai berikut.
a. Asas mengikutsertakan.
b. Asas komunikasi.
c. Asas pengakuan.
d. Asas wewenang yang didelegasikan.
e. Asas adil dan layak.
f. Asas perhatian timbal balik.

Untuk mengetahui sejauh mana pelaksanaan motivasi yang dilakukan oleh pemerintah daerah dalam meningkatkan kualitas pelayanan publik pada pemerintah daerah, yang pembahasannya didasarkan pada asas-asas motivasi adalah sebagai berikut.

\section{Asas Mengikutsertakan}

Pimpinan berusaha memberikan kesempatan kepada bawahannya untuk mengambil keputusan di bidang tugasnya masing-masing sehingga para bawahan merasa diberi keleluasaan bergerak dan berpikir di dalam menjalankan tugasnya, dengan demikian para pegawai merasa turut diikutsertakan di dalam proses pencapaian tujuan organisasi, yang pada akhirnya diharapkan akan berpengaruh terhadap peningkatan semangat serta gairah kerja pegawai.

Selain itu seorang pimpinan organisasi dalam melaksanakan motivasinya harus senantiasa memperhatikan setiap saran maupun ide yang disampaikan oleh para pegawai, hal ini akan mendorong setiap pegawai turut bertanggung jawab di dalam setiap proses kerja, karena mereka merasa turut dilibatkan dalam setiap pengambilan keputusan.

Untuk mengetahui tentang penerapan asas mengikutsertakan oleh pemerintah daerah Kabupaten Sumedang di dalam pelaksanaan motivasinya, maka dilakukan penelitian terhadap dua subvariabel dari asas mengikutsertakan, yaitu :

\section{- Mengikutsertakan pegawai dalam mengambil keputusan}

Guna mencapai kualitas pelayanan pada pemerintah daerah, dalam pelaksanaan motivasinya pemerintah daerah dituntut untuk memberikan kesempatan kepada para pegawai dalam mengambil keputusan yang berkaitan dengan bidang tugasnya masing-masing, dalam hal ini para 
pegawai akan termotivasi untuk lebih berusaha meningkatkan semangat serta disiplin kerjanya, karena mereka merasa diberi kepercayaan oleh pimpinannya. dari hal tersebut tanggapan responden dalam mengikuti sertakan pegawai dalam mengambil keputusan yaitu; Sebanyak 31 responden (72\%) menyatakan bahwa kesempatan mengambil keputusan, para pegawai telah cukup diberi keleluasaan oleh pemerintah daerah untuk mengambil keputusan di bidang tugasnya, sedangkan sebanyak 8 responden (19\%) menyatakan bahwa mereka masih kadang-kadang diberi kesempatan dalam mengambil keputusan di bidang tugasnya, dan sebanyak 4 orang (9\%) menyatakan bahwa mereka tidak pernah diberi kesempatan untuk mengambil suatu keputusan di bidang tugasnya.

Dari tanggapan responden di atas dapat disimpulkan bahwa pemerintah daerah dalam pelaksanaan motivasinya ternyata sudah cukup baik, namun perlu ditingkatkan lagi dalam memberikan kesempatan pada pegawai untuk pengambilan keputusan di bidang tugasnya masing-masing, sehingga akan memotivasi dan meningkatkan semangat kerja pegawai.

Berdasarkan hasil observasi nampak bahwapelaksanaan motivasi oleh pemerintah daerah dengan indikator mengikutsertakan pegawai dalam mengambil keputusan telah dilaksanakan dengan cukup baik. Hal ini dapat dibuktikan dengan adanya tanggapan responden sebanyak 31 (72\%) menyatakan bahwa mereka cukup diberi kesempatan oleh pemerintah daerah dalam keikutserta an mengambil keputusan terutama di bidang tugasnya.

Berdasarkan wawancara melalui
pemerintah daerah bahwa ketika
memecahkan suatu masalah yang
sekiranya perlu dibahas bersama, selalu
mengikutsertakan bawahan guna mencari
pemecahan dari masalah yang dihadapi.

\section{- Bersikap terbuka terhadap saran atau ide dari pegawai}

Tercapainya kualitas pelayanan publik pada pemerintah daerah, pemerintah daerah senantiasa memperhatikan saran atau ide yang disampaikan oleh para pegawai agar dengan sendirinya tumbuh rasa dihargai keberadaannya di dalam proses pelaksanaan pekerjaan yang pada akhirnya timbul semangat dan gairah untuk bekerja. Sifat terbuka sangat penting untuk ditumbuhkan dalam organisasi agar tidak terjadi kesalahpahaman dalam organisasi.

Dari hal tersebut tanggapan responden tentang sifat keterbukaan, yaitu: sebanyak 29 responden (68\%) menyatakan ya, bahwa pemerintah daerah selalu memberikan kesempatan kepada pegawai untuk mengajukan saran atau ide, telah dilaksanakan dengan baik, sedang kansebanyak 5 responden (12\%) menyatakan bahwa mereka masih kadang-kadang diberi kesempatan kepada para pegawai untuk mengajukan saran atau ide, dan sebanyak 9 orang $(20 \%)$ menyatakan bahwa mereka tidak pernah diberi kesempatan untuk mengajukan saran atau ide.

Dari tanggapan responden di atas dapat disimpulkan bahwa pemerintah daerah dalam pelaksanaan motivasinya ternyata sudah dilaksanakan dengan cukup baik, namun perlu ditingkatkan lagi guna meningkatkan semangat kerja di dalam pelaksanaan tugasnya yang pada akhirnya dapat memberikan pelayanan terhadap masyarakat dengan baik.

Berdasarkan observasi, pemerintah daerah berusaha memberikan kesempatan kepada para pegawai untuk mengajukan saran atau ide tetapi belum terlaksana secara optimal dikarenakan masih terdapat beberapa pegawai yang menyampaikan saran atau ide yang tidak sesuai dengan konteks masalah yang dihadapi, hal ini menunjukkan suatu bukti bahwa masih adanya perbedaan pengetahuan serta kemampuan di antara pegawai. 
Berdasarkan wawancara pemerintah daerah sudah berusaha memperhatikan saran atau ide dari para pegawai agar tercipta suatu keharmonisan yang mendorong terhadap kemajuan organisasi, namun karena yang disampaikan sering tidak proporsional maka terkesan seakan tidak ditanggapi.

\section{Asas Komunikasi}

Pemerintah daerah dalam pelaksanaan gagasan atau inovasi dituntut untuk menerapkan asas komunikasi, yang artinya pemerintah daerah diharapkan mampu memberikan informasi secara jelas kepada para pegawai tentang tujuan yang hendak dicapai. Dengan adanya komunikasi yang jelas, akan mendorong pegawai untuk lebih produktif, karena semakin banyak seseorang mengetahui suatu masalah, semakin besar pula minat dan perhatiannya terhadap hal tersebut.

Untuk mengetahui sejauh mana pelaksanaan asas komunikasi yang dilakukan oleh pemerintah daerah dalam melaksanakan inovasi, penulis meneliti dua indikator dari asas komunikasi, yaitu :

\section{- Menciptakan komunikasi dua arah.}

Keberhasilan pelaksanaan motivasi dalam meningkatkan kualitas pelayanan kepada masyarakat sangat bergantung pada kemampuan pimpinan dalam menciptakan komunikasi dua arah karena melalui cara ini dapat menciptakan adanya saling pengertian di antara pegawai dalam pelaksanaan tugasnya, sehingga akan berpengaruh terhadap peningkatan kualitas pelayanan. dari hal tersebut tanggapan responden dalam menciptakan komunikasi dua arah dalam pelaksanaan inovasi pemerintah daerah, yaitu: sebanyak 28 responden (65\%) menyatakan ya, bahwa pemerintah daerah selalu berusaha menyampaikan komunikasi dua arah terhadap para pegawainya, sedangkan 8 responden (18\%) menyatakan bahwa pemerintah daerah kadang-kadang berusaha menyampaikan komunikasi terhadap para pegawainya, dan sebanyak 7 responden (17\%) menyatakan bahwa pemerintah daerah tidak pernah berusaha menyampaikan komunikasi dua arah terhadap para pegawainya.

Dari tanggapan responden tersebut, dapat ditarik simpulan bahwa pemerintah daerah dalam pelaksanaan motivasinya ternyata sudah diterapkan dengan cukup baik, namun masih dituntut untuk lebih berusaha lagi untuk mewujudkan adanya saling pengertian dan kerja sama di antara pegawai yang pada akhirnya akan berpengaruh terhadap peningkatan kualitas pelayanan.

Berdasarkan observasi menunjukkan bahwa di antara pegawai masih terdapat adanya salah pengertian tentang proses pelaksanaan pekerjaan dan sering terjadinya tugas dari masing-masing bi dan gnya yang selalu bentrok dengan jadwal kegiatan, hal ini jelas menunjukkan bahwa terdapat hambatan di dalam proses komunikasi.

Berdasarkan wawancara diperoleh keterangan bahwa pemerintah daerah selalu berupaya untuk melakukan komunikasi dua arah tersebut, tetapi karena adanya perbedaan individu pegawai, misalnya kurang perhatian dan kurang menerima sepenuh hati, maka komunikasi ini menjadi agak terhambat.

\section{- Penggunaan bahasa yang mudah dimengerti.}

Penyampaian informasi akan mendapat hasil yang optimal bila menggunakan bahasa yang mudah dimengerti, sehingga para pegawai benar-benar dapat memahami dengan jelasi informasi yang diterimanya dan memudahkan di dalam pelaksanaan pekerjaannya sesuai dengan yang diinginkan dan pada akhirnya akan berpengaruh terhadap peningkatan kualitas pelayanan guna memuaskan masyarakat yang menerima pelayanan. 
Dari hal tersebut tanggapan responden dalam Penggunaan bahasa yang mudah dimengerti dalam rangka pelaksanaan inovasi pemerintah daerah, yaitu: sebanyak 34 responden (79\%) menyatakan ya, bahwa pemerintah daerah berusaha menyampaikan informasi dengan menggunakan bahasa yang mudah dimengerti, sedangkan sebanyak 5 responden (12\%) menyatakan bahwa pemerintah daerah masih kadangkadang menyampaikan informasi dengan menggunakan bahasa yang mudah dimengerti, dan sebanyak 4 responden (9\%) menyatakan bahwa pemerintah daerah tidak pernah menyampaikan informasi dengan menggunakan bahasa yang mudah dimengerti.

Berdasarkan tanggapan responden maka dapat ditarik simpulan bahwa dalam pelaksanaan motivasinya pemerintah daerah telah menggunakan bahasa yang mudah dimengerti, sehingga memudahkan para pegawai dalam memahami tentang tugas-tugas serta fungsinya yang berkenaan dengan pelaksanaan tugas pekerjaan yang pada akhirnya berpengaruh terhadap peningkatan kualitas pelayanan publik.

Berdasarkan hasil observasi, dalam setiap pertemuan atau rapat pemerintah daerah selalu menggunakan bahasa yang mudah dimengerti baik dalam pemberian informasi maupun pengarahan. Hal ini dibutikan dengan daya pemahaman tinggi dari pegawai, telah tercermin dari pelaksanaan kerjanya sudah sesuai dengan instruksi.

Berdasarkan wawancara diperoleh keterangan bahwa di dalam memberikan informasi senantiasa disampaikan dengan bahasa yang mudah dimengerti, hal ini dilakukan untuk memudahkan pemahaman pegawai tentang isi informasi dimaksud.

\section{Asas Pengakuan}

Pengakuan merupakan prinsip untuk menghargai manusia pada derajat sebenarnya sebagai makhluk berbudi dan berakhlak dalam menjalankan kehidupan sehari-hari. pada dasarnya setiap pegawai menginginkan dirinya diperlukan sebagai manusia yang mempunyai hasrat ingin dihargai, diperhatikan dan sebagainya, baik di lingkungan tempat bekerja maupun di masyarakat. Oleh karena itu seorang pimpinan organisasi harus menerapkan asas pengakuan di dalam pelaksanaan motivasinya, yaitu melalui pemberian penghargaan kepada pegawai yang berprestasi sehingga mereka benarbenar merasa dihargai jerih payahnya dan memotivasi untuk lebih meningkatkan lagi prestasi kerjanya.

Di samping itu untuk menumbuhkan adanya prestasi kerja yang baik, perlu menciptakan adanya persaingan yang sehat di antara para pegawai. Bila hal ini telah dilakukan, dengan sendirinya para pegawai di dalam pelaksanaan tugas pekerjaannya senantiasa mempunyai semangat serta disiplin kerja tinggi sehingga pada akhirnya akan berpengaruh terhadap peningkatan kualitas pelayanan.

Untuk mengetahui tentang pelaksanaan asas pengakuan oleh pemerintah daerah dalam pelaksanaan inovasi, maka penulis melakukan penelitian terhadap dua sub variabel dari asas motivasi, yaitu sebagai berikut.

\section{- Penghargaan untuk pegawai yang berprestasi}

Untuk mencapai sasaran kerjamenyangkut kualitas pelayanan, maka seorang pimpinan di dalam pelaksanaan motivasinya harus berusaha memberikan penghargaan kepada pegawai yang berprestasi, baik bersifat material maupun non material sebagai wujud adanya pengakuan sehingga mendorong pegawai untuk meningkatkan lagi prestasi kerjanya sehingga sasaran yang ingin dicapai, yaitu meningkatkan kualitas pelayanan terhadap masyarakat. Dengan hal tersebut 
tanggapan responden dalam Penghargaan untuk pegawai berprestasi dalam rangka pelaksanaan inovasi pemerintah daerah, yaitu: sebanyak 26 responden (60\%) menyatakan ya, bahwa pemerintah daerah selalu memberikan penghargaan untuk pegawai yang berprestasi, sedangkan sebanyak 10 responden (23\%) menyatakan bahwa pemerintah daerah masih kadangkadang memberikan penghargaan bagi para pegawai yang berprestasi, dan sebanyak 7 responden (17\%) menyatakan bahwa pemerintah daerah tidak pernah memberikan penghargaan untuk pegawai yang berprestasi.

Berdasarkan tanggapan responden di atas dapat ditarik simpulan bahwa pemerintah daerah dalam pelaksanaan motivasinya telah cukup berusaha untuk memberikan penghargaan bagi pegawai yang berprestasi.

Berdasarkan hasil observasi menunjukkan bahwa setiap ada pegawai yang mendapat kan penghargaan dari pemerintah, pemerintah daerah juga tidak lupa memberikan penghargaan untuk pegawai tersebut, walaupun hanya sebatas ucapan selamat.

Berdasarkan wawancara diperoleh keterangan bahwa setiap pegawai yang berprestasi selalu diupayakan suatu penghargaan sebagai wujud pengakuan baik yang bersifat material maupun non material, namun masih ada kendala karena adanya keterbatasan dana sehingga penghargaan yang diberikan kepada pegawai yang berprestasi hanya diberikan penghargaan non material, yaitu berupa ucapan selamat.

\section{- Menciptakan persaingan sehat.}

Untuk lebih meningkatkan kualitas pelayanan, pemerintah daerah perlu menciptakan persaingan yang sehat di antara para pegawai, sehingga para pegawai akan terpacu dan berlomba-lomba untuk lebih giat dan mencapai prestasi yang diharapkan. Apabila asas pengakuan dengan kedua indikatornya dapat dilaksanakan dengan baik oleh pemerintah daerah, maka kualitas pelayanan akan meningkat dengan pencapaian tujuan yang optimal. dari hal tersebut tanggapan responden tentang menciptakan persaingan sehat, yaitu: sebanyak 20 responden (46\%) menyatakan ya, bahwa pemerintah daerah berusaha menciptakan persaingan sehat antarpegawai, sedangkan sebanyak 18 responden (42\%) menyatakan bahwa pemerintah daerah masih kadang-kadang menciptakan persaingan sehat antarpegawai, dan sebanyak 5 responden $(12 \%)$ menyatakan bahwa pemerintah daerah tidak pernah menciptakan persaingan sehat antarpegawai.

Berdasarkan observasi menunjukkan bahwa pemerintah daerah masih belum sepenuhnya menerapkan asas pengakuan dengan indikator menciptakan persaingan sehat antarpegawai, sehingga para pegawai tidak ber keinginan untuk menjadi pegawai yang berprestasi, karena yang berprestasi atau tidak berprestasi, tetap saja pemerintah daerah jarang memberikan penghargaan kepada pegawai yang berprestasi, sehingga bagi para pegawai tidak ada persaingan sehat dalam organisasinya.

Berdasarkan wawancara diperoleh hasil bahwa pemerintah daerah sudah berusaha memberikan kebebasan para pegawai untuk berprestasi dan menciptakan persaingan yang sehat di antara pegawai, namun di dalam pelaksanaannya belum terlaksanan secara optimal, karena masih banyak pegawai yang berpendidikan masih umum dan rendah (SMA).

\section{Asas Wewenang yang Didelegasikan.}

Dalam pelaksanaan tugas dan tanggung jawabnya, pemerintah daerah tidak harus bekerja sendiri, untuk itu perlu adanya pendelegasian wewenang. Artinya pemerintah daerah mendelegasikan sebagian wewenang serta kebebasan pegawai untuk mengambil keputusan dan beraktivitas 
terhadap pekerjaannya serta melaksanakan tugas-tugas atasan apabila berhalangan. yang perlu diingat dalam pendelegasian wewenang, pemerintah daerah harus meyakinkan bawahan bahwa pegawai mampu dan dipercaya dapat menyelesaikan tugas-tugas yang dibebankan dengan baik. Dengan pelaksanaan asas wewenang yang didelegasikan ini, akan memotivasi moral atau gairah kerja pegawai semakin tinggi.

Untuk mengetahui tentang pelaksanaan asas wewenang yang didelegasikan oleh pemerintah daerah, maka penulis melakukan penelitian terhadap dua subvariabel dari asas motivasi, yaitu sebagai berikut.

\section{- Wewenang diberikan kepada orang yang tepat}

Pendelegasian wewenang yang harus diberikan kepada orang atau petugas yang tepat, artinya sesuai dengan bidang tugas dan keahlian yang bersangkutan. Bila hal ini telah dilakukan oleh pimpinan organisasi, dengan sendirinya bias memudahkan proses pencapaian tujuan organisasi dan menghilangkan kecemburuan di antara para pegawai dalam melaksanakan pekerjaan. dari hal tersebut tanggapan responden tentang wewenang yang diberikan kepada orang yang tepat dengan tanggapan responden, yaitu: sebanyak 25 responden (58\%) menyatakan ya, bahwa pemerintah daerah berusaha memberikan wewenang yang didelegasikan kepada pegawainya, sedangkan 10 responden (24\%) menyatakan bahwa pemerintah daerah masih kadangkadang memberikan wewenang yang didelegasikan, dan sebanyak 8 responden (18\%) menyatakan bahwa pemerintah daerah tidak pernah memberikan wewenang yang didelegasikan.

Berdasarkan observasi penulis melihat bahwa pemberian wewenang sering kali tidak disesuaikan dengan bidang tugas pegawai, hal ini menunjukkan bahwa kemampuan serta keahlian pegawai belum merata.
Berdasarkan hasil wawancara penulis memperoleh keterangan bahwa pemberian wewenang kepada pegawai yang tepat masih terdapat kendala, yaitu masih adanya perbedaan terhadap individu pegawai, karena adanya perbedaan tingkat keahlian pegawai yang tidak merata dalam bidang tugasnya masing-masing.

\section{- Pemberian wewenang disertai dengan tanggung jawab}

Dalam pelaksanaan inovasi dalam memotivasi pimpinan organisasi harus berusaha untuk menyertai tanggung jawab dalam memberikan wewenangnya tersebut, yang artinya harus adanya bimbingan a dan pembinaan serta pengarahan kepada pegawai bahwa setiap wewenang harus ada pertanggungjawabannya. Dengan melalui upaya ini dapat menumbuhkan sikap disiplin pada diri pegawai dan senantiasa dapat terawasi dalam pelaksanaan tugasnya. Tanggapan responden dalam hal pemberian wewenang disertai dengan tanggung jawab, yaitu: sebanyak 27 responden (62\%) menyatakan ya, bahwa pemerintah daerah berusaha untuk menekankan adanya pertanggungjawaban dalam setiap pendelegasian wewenang, sedang kansebanyak 11 responden (26\%) menyatakan bahwa pemerintah daerah masih kadang-kadang menyertakan tanggung jawab dalam setiap pendelegasian wewenang, dan sebanyak 5 responden (12\%) menyatakan bahwa pemerintah daerah tidak pernah menyertakan tanggung jawab dalam setiap pendelegasian wewenang.

Berdasarkan tanggapan responden tersebut, maka dapat ditarik simpulan bahwa dalam pendelegasian wewenang sudah terlaksana walaupun belum sepenuhnya, untuk itu pemerintah daerah dituntut untuk lebih berusaha lagi untuk menekankan adanya pertanggungjawaban dalam setiap pendelegasian wewenang tersebut.

Berdasarkan dari observasi penulis melihat bahwa masih ada sebagian pegawai 
yang kurang mampu dalam memberikan laporan pertanggungjawaban dalam pendelegasian wewenang yang diberikan oleh pemerintah daerah kepadanya pada akhir pelaksanaan tugasnya.

Berdasarkan wawancara diperoleh keterangan bahwa untuk menekankan adanya pertanggungjawaban pada setiap pendelegasian wewenang pada dasarnyatelah diusahakan, namun karena adanya perbedaan kemampuan serta pengetahuan dari pegawai maka masih terdapat pegawai yang kurang mampu mempertanggungjawabkan pelaksanaan tugasnya.

\section{Asas Adil dan Layak}

Dalam pelaksanaan inovasi pemerintah daerah dalam memotivasinya dituntut untuk menerapkan asas adil dan layak. pemerintah daerah dalam hal ini berfungsi untuk memperlakukan pegawai secara adil dan layak, artinya segala pengorbanan yang dilakukan oleh para pegawai harus seimbang dengan imbalan yang mereka terima.

Untuk mengetahui tentang pelaksanaan asas adil dan layak oleh pemerintah daerah, penulis melakukan penelitian terhadap dua sub variabel dari asas motivasi, yaitu sebagai berikut.

\section{- Memperlakukan pegawai secara adil dan layak.}

Keberhasilan pelaksanaan inovasi pemerintah daerah memotivasinya untuk meningkatkan kualitas pelayanan terhadap masyarakat, tergantung kepada kemampuan pemerintah daerah dalam memperlakukan para pegawai secara adil dan layak, karena melalui cara ini dapat menjadikan para pegawai merasa kemampuan dan keterampilannya dapat dihargai secara wajar melalui gaji, pujian dari pimpinan, dan promosi jabatan.

Tanggapan responden memperlakukan pegawai secara adil dan layak, yaitu: sebanyak 32 responden (74\%) menyatakan ya, bahwa pemerintah daerah berusaha memperlakukan pegawai secara adil dan layak, sedangkan sebanyak 7 responden $(17 \%)$ menyatakan bahwa pemerintah daerah masih kadang-kadang memperlakukan pegawai secara adil dan layak, dan sebanyak 4 responden (9\%) menyatakan bahwa pemerintah daerah tidak pernah memperlakukan pegawai secara adil dan layak. Berdasarkan tanggapan responden di atas, maka dapat ditarik simpulan bahwa dalam pelaksanaan motivasinya pemerintah daerah telah berupaya untuk, memperlakukan pegawai secara adil dan layak kepada pegawai akan tetapi belum sepenuhnya terlaksananya dengan baik.

Berdasarkan hasil observasi terlihat bahwa masih adanya pegawai yang belum merasa diperlakukan secara adil dan layak, artinya mereka masih merasa belum puas dengan apa yang pemerintah daerah berikan ketika para pegawai melaksanakan tugas dengan baik.

Berdasarkan hasil wawancara penulis memperoleh keterangan bahwa pemerintah daerah dalam hal ini sudah cukup berusaha memperlakukan pegawai secara adil dan layak, tetapi masih ada hambatan dalam pelaksanaannya dikarenakan adanya perbedaan keinginan dari masing-masing individu.

\section{- Memberikan hadiah atau hukuman secara adil dan layak}

Memberikan hadiah atau hukuman secara adil dan layak akan merangsang para pegawai untuk lebih bersemangat dan bergairah di dalam melaksanakan pekerjaannya, selain itu para pegawai juga akan lebih disiplin dalam bekerja bila pemerintah daerah dalam hal ini mampu menerapkannya secara optimal. Bagi pegawai yang prestasinya beda diharapkan pemerintah daerah harus adil dalam memberikan penghargaan atau hadiah yang diterima tergantung pada prestasi kerjanya. 
Tanggapan responden dalam memberikan hadiah atau hukuman secara adil dan layak, yaitu: sebanyak 26 responden $(60 \%)$ menyatakan ya, bahwa pemerintah daerah selalu memberikan hadiah atau hukuman secara adil dan layak, sedangkan sebanyak 9 responden (21\%) menyatakan bahwa pemerintah daerah masih kadang-kadang memberikan hadiah atau hukuman secara adil dan layak, dan sebanyak 8 responden (19\%) menyatakan bahwa pemerintah daerah tidak pernah memberikan hadiah atau hukuman secara adil dan layak.

Berdasarkan observasi terlihat bahwa pemerintah daerah sudah cukup berusaha tetapi karena perbedaan keinginan dari masing-masing pegawai sehingga pemerintah daerah belum bisa memenuhi semua apa yang diinginkan oleh pegawai, dalam hal pemberian hadiah dikarenakan kurangnya dana.

Berdasarkan wawancara diperoleh hasil bahwa pemerintah daerah selalu berupaya untuk tegas dan berusaha untuk memberikan hadiah kepada para pegawai tetapi karena keterbatasan dana sehingga belum bias terpenuhi semua.

\section{Asas Perhatian Timbal Balik}

Dalam pelaksanaan motivasi,
pemerintah daerah dituntut untuk menerapkan asas perhatian timbal balik di mana pemerintah daerah berfungsi untuk memberikan penjelasan kepada pegawai tentang apa yang diharapkan atau apa yang diinginkan oleh organisasi, di samping berusaha untuk memenuhi kebutuhankebutuhan pegawai, baik kebutuhan yang berhubungan dengan pekerjaan maupun kebutuhan hidupnya seperti sarana dan prasarana yang memadai dan suasana kerja yang menyenangkan. Dengan demikian pegawai akan merasa puas dan mengacu untuk lebih meningkatkan kualitas pelayanan terhadap masyarakat.
Untuk mengetahui tentang pelaksanaan asas timbal balik oleh pemerintah daerah, maka penulis melakukan penelitian terhadap dua sub variabel dari asas motivasi berikut.

\section{- Memenuhi sarana dan prasarana kerja}

Kualitas pelayanan terhadap masyarakat dapat meningkat bila pimpinan organisasi berusaha untuk memenuhi fasilitas kerja yang diperlukan oleh pegawai agar dalam pelaksanaan kerjanya pegawai akan merasa bersemangat ketika mengerjakan tugas.

Tanggapan responden tentang memenuhi sarana dan prasarana kerja, yaitu: sebanyak 27 responden (62\%) menyatakan ya, bahwa pemerintah daerah berusaha memenuhi sarana dan prasarana kerja, sedangkan sebanyak 10 responden (24\%) menyatakan bahwa pemerintah daerah masih kadang-kadang memenuhi sarana dan prasarana kerja, dan sebanyak 6 responden (14\%) menyatakan bahwa pemerintah daerah tidak pernah memenuhi sarana dan prasarana kerja.

Berdasarkan observasi terlihat bahwa dari tiap unit kerja memang sudah ada fasilitas pendukung dalam pekerjaan, akan tetapi jumlahnya yang terbatas dan ada beberapa perlengkapan yang kondisinya sudah tidak layak pakai tapi masih tetap digunakan.

Berdasarkan hasil wawancara penulis memperoleh keterangan bahwa untuk memenuhi ketersediaan fasilitas kerja menemui beberapa kendala di antaranya terbatasnya dana sehingga belum sepenuhnya fasilitas dapat dipenuhi.

\section{- Suasana kerja yang menyenangkan}

Suasana kerja yang menyenangkan akan merangsang pegawai untuk bersemangat dan bergairah di dalam pelaksanaan tugasnya, sehingga akan berpengaruh terhadap kualitas pelayanan publik. Oleh karena itu merupakan kewajiban 
bagi seorang pimpinan organisasi untuk berusaha menciptakan suasana kerja yang menyenangkan sehingga tercipta hubungan yang harmonis antara para pegawai di dalam pelaksanaan inovasi dalam asas motivasi, Tanggapan responden tentang Suasana kerja yang menyenangkan Sebanyak 28 responden (65\%) menyatakan ya, bahwa pemerintah daerah berusaha menciptakan suasana kerja yang menyenangkan, sedangkan sebanyak 8 responden (18\%) menyatakan bahwa pemerintah daerah masih kadang-kadang berusaha menciptakan suasana kerja yang menyenangkan, dan sebanyak 7 responden (17\%) menyatakan bahwa pemerintah daerah tidak berusaha menciptakan suasana kerja yang menyenangkan.

Berdasarkan observasi Nampak bahwa dalam proses kerja masih terdapat sebagian pegawai yang kurang mampu melakukan kerja sama maupun berkomunikasi secara akrab dengan sesama pegawai.

Berdasarkan hasil wawancara diperoleh keterangan ternyata untuk menciptakan suasana lingkungan kerja yang menyenangkan selalu dilakukan dengan cara pembinaan kekeluargaan yang lebih mantap, tetapi masih mendapat hambatan berupa masih adanya perbedaan individu sehingga menghambat timbulnya kebersamaan serta kerja sama di antara pegawai.

Memperhatikan uraian di atas dapat ditarik simpulan bahwa di dalam pelaksanaan motivasinya ternyata pemerintah daerah masih perlu berusaha lagi di dalam menerapkan asas-asas motivasi. Hal ini terbukti dari rata-rata rekapitulasi nilai tertinggi dalam menerapkan asas-asas motivasi pemerintah daerah baru mencapai 64\%. Jadi apabila dihubungkan dengan standar penilaian pelaksanaan motivasi maka pelaksanaan motivasi oleh pemerintah daerah baru mencapai predikat cukup.

Untuk mengetahui keseluruhan dari penerapan asas-asas motivasi berikut predikatnya adalah sebagai berikut.
1. Asas Mengikutsertakan70\% (Cukup)

2. Asas Komunikasi72\% (Cukup)

3. Asas Pengakuan53\% (Kurang Baik)

4. Asas wewenang yang Didelegasikan60\% (Cukup)

5. Asas Adil dan Layak67\% (Cukup)

6. Asas Timbal Balik63\% (Cukup)

Jadi motivasi oleh pemerintah daerah secara keseluruhan telah dilaksanakan dengan cukup baik, hanya saja masih ada beberapa asas-asas yang belum dapat dilaksanakan secara maksimal.

\section{Tangibles (bukti langsung)}

\section{- Sarana kerja memadai}

Berdasarkan tanggapan responden bahwa sarana dan prasarana yang ada belum sepenuhnya memadai, Hal ini dibuktikan dengan adanya sebagian besar tanggapan responden, yaitu sebanyak 27orang (62\%) menyatakan bahwa sarana dan prasarana kantor sudah cukup memadai.

Berdasarkan observasi terlihat bahwa sarana dan prasarana sudah disediakan, namun masih perlu adanya penambahan atau pengadaan fasilitas agar dapat menunjang pencapaian kualitas pelayanan publik.

Berdasarkan wawancara diperoleh keterangan bahwa dalam memberikan pelayanan publik sudah cukup berusaha menyediakan sarana dan prasarana yang memadai, namun belum semuanya terpenuhi, hal ini karena masih keterbatasannya dana.

\section{- Suasana tempat kerja nyaman/ menyenangkan.}

Berdasarkan tanggapan responden bahwa para pegawai belum sepenuhnya merasa nyaman pada saat bekerja, hal ini dapat dibuktikan dengan adanya sebagian besar tanggapan responden, yaitu sebanyak 28 orang (65\%) menyatakan bahwa mereka sudah diberikan tempat kerja yang cukup nyaman. 
Berdasarkan hasil observasi terlihat bahwa suasana tempat kerja yang nyaman/ menyenangkan belum sepenuhnya terpenuhi, hal ini dilihat dari ada sebagian ruangan yang ukurannya kecil tetapi di huni oleh beberapa orang, tentunya hal ini membuat kurang nyaman pegawai di dalam pelaksanaan kerjanya untuk itu perlu adanya penataan ruang yang lebih baik.

Berdasarkan hasil wawancara diperoleh keterangan ternyata untuk menciptakan suasana lingkungan kerja yang nyaman/ menyenangkan sudah dilaksanakan tetapi karena keterbatasan dana untuk memenuhi fasilitas yang ada belum terlaksana secara maksimal.

\section{Reliability (kehandalan)}

\section{- Kemampuan petugas dalam memberikan pelayanan}

Berdasarkan tanggapan responden diambil dari sebagian besar yang menjawab, yaitu sebanyak 30 orang (69\%) menyatakan bahwa di dalam pelaksanaan pelayanan publik pegawai sudah cukup berusaha memberikan pelayanan yang baik.

Berdasarkan observasi Nampak bahwa di dalam pelaksanaan pelayanan publik, pegawai sudah cukup mampu memberikan pelayanan kepada masyarakat, namun masih perlu ditingkatkan lagi, karena masingmasing pegawai memiliki kemampuan dan keahlian yang berbeda.

Berdasarkan wawancara diperoleh hasil bahwa di dalam pelaksanaan pelayanan publik sudah cukup mampu memberikan pelayanan yang baik terhadap masyarakat, dikarenakan kemampuan dan keahlian pegawai yang belum merata sehingga perlu adanya peningkatan kualitas pegawai misalnya ilmu atau wawasan serta kreativitas pegawai melalui peningkatan pendidikan atau pelatihan agar kualitas pelayanan juga meningkat.

\section{- Kehandalan/pengalaman pegawai}

Berdasarkan tanggapan responden diambil dari sebagian besar yang menjawab, yaitu sebanyak 28 orang (65\%) menyatakan bahwa pegawai sudah cukup handal dan mempunyai pengalaman di dalam memberikan pelayanan terhadap masyarakat.

Berdasarkan observasi terlihat bahwa di dalam pelaksanaan pelayanan publik pegawai sudah cukup handal atau berpengalaman dalam memberikan pelayanan kepada masyarakat, namun masih perlu ditingkatkan lagi karena perbedaan lamanya masa kerja sehingga masih terdapat pegawai yang belum berpengalaman dalam memberikan pelayanan.

Berdasarkan wawancara diperoleh hasil bahwa di dalam pelaksanaan pelayanan publik selalu memberikan pengarahan serta bimbingan kepada pegawai yang belum cukup pengalaman agar mereka dapat lebih profesional lagi dalam memberikan pelayanan.

\section{Responsive (ketanggapan)}

\section{- Kesanggupan pegawai dalam memberikan pelayanan dengan cepat}

Berdasarkan tanggapan responden diambil dari sebagian besar yang menjawab, yaitu sebanyak 22 orang (51\%) menyatakan bahwa pegawai dalam memberikan pelayanan dengan cepat belum dilaksanakan dengan baik, karena sarana dan prasarana yang kurang menunjang dalam pelaksanaan pelayanan publik.

Berdasarkan observasi terlihat bahwa dalam pelaksanaan pelayanan publik sudah berusaha agar pelayanan diselesaikan dengan cepat, karena terbatasnya sarana dan prasarana sehingga hal ini menjadi penghambat dalam mencapai kualitas pelayanan publik. 
Berdasarkan wawancara diperoleh hasil bahwa dalam memberikan pelayanan publik dengan cepat masih belum dapat dilaksanakan dengan baik, hal ini karena waktu penyelesaian yang tidak dapat ditentukan misalnya pembuatan kartu keluarga (KK) bisa mencapai 1 minggu dikarenakan proses penyelesaiannya di Dinas Kependudukan dan Pencatatan Sipil Kabupaten Sumedang.

\section{- Memberikan pelayanan dengan tepat.}

Berdasarkan tanggapan responden diambil dari sebagian besar yang menjawab, yaitu sebanyak 29 orang (68\%) menyatakan bahwa pegawai sudah cukup baik dalam memberikan pelayanan dengan tepat sesuai prosedur, hal ini berpengaruh terhadap peningkatan kualitas pelayanan publik.

Berdasarkan observasi terlihat bahwa dalam melaksanakan pelayanan publik pegawai sudah cukup berusaha memberikan pelayanan dengan tepat sesuai prosedur, hal ini berpengaruh terhadap kepuasan masyarakat dalam menerima pelayanan.

Berdasarkan wawancara diperoleh hasil bahwa di dalam pelaksanaan pelayanan publik selalu memberikan pengarahan pada pegawai agar selalu memberikan pelayanan dengan tepat sesuai prosedur agar masyarakat yang menerima pelayanan merasa puas.

\section{Assurance (jaminan)}

\section{- Pegawai tidak membeda-bedakan masyarakat yang dilayani.}

Berdasarkan tanggapan responden diambil dari sebagian besar yang menjawab, yaitu sebanyak 25 orang (58\%) menyatakan bahwa masih ada sebagian pegawai yang masih membeda-bedakan masyarakat yang dilayani.

Berdasarkan observasi terlihat bahwa masih ada sebagian pegawai yang masih membeda-bedakan masyarakat yang dilayani, sehingga mereka belum sepenuhnya merasa puas dengan pelayanan publik yang diterima. Hal ini menjadi faktor pendukung bagi masyarakat untuk memberikan penilaian atas pelayanan yang diberikan.

Berdasarkan wawancara diperoleh hasil bahwa dalam pelaksanaan pelayanan publik selalu mengingatkan pegawai agar dapat lebih konsisten melaksanakan pelayanan dengan tidak membeda-bedakan masyarakat yang dilayani sehingga masyarakat merasa puas dengan pelayanan publik yang diterima.

- Keramahan petugas dalam memberikan pelayanan terhadap masyarakat.

Berdasarkan tanggapan responden diambil dari sebagian besar yang menjawab, yaitu sebanyak 28 orang (65\%) menyatakan bahwa pegawai sudah berusaha cukup ramah dalam memberikan pelayanan kepada masyarakat.

Berdasarkan observasi terlihat bahwa dalam memberikan pelayanan kepada masyarakat, pegawai sudah cukup bersikap ramah kepada masyarakat, namun masih perlu ditingkatkan lagi agar masyarakat dapat menilai dengan baik kualitas pelayanan yang diberikan.

Berdasarkan wawancara diperoleh hasil bahwa dalam pelaksanaan pelayanan publik selalu ditegaskan untuk bersikap ramah ketika memberikan pelayanan, agar masyarakat merasakan kenyamanan pada saat menerima pelayanan.

\section{Empathy}

\section{- Perhatian pribadi pegawai terhadap masyarakat yang membutuhkan pelayanan.}

Berdasarkan tanggapan responden diambil dari sebagian besar yang menjawab, yaitu sebanyak 29 orang (68\%) menyatakan bahwa pegawai sudah cukup berusaha 
memberikan perhatian terhadap masyarakat yang membutuhkan pelayanan.

Berdasarkan observasi terlihat bahwa pegawai sudah cukup perhatian terhadap masyarakat yang membutuhkan pelayanan, tetapi masih perlu ditingkatkan lagi karena masyarakat selalu ingin dilayani dengan jujur agar bisa terjalin hubungan yang baik antara pegawai dengan masyarakat yang membutuhkan pelayanan.

Berdasarkan wawancara diperoleh hasil bahwa selalu diberi pengarahan kepada pegawai agar dalam pelaksanaan publik diharapkan memberikan penjelasan dengan sejujur-ujurnya, jangan merasa berjasa dalam memberikan pelayanan agar tidak timbul keinginan untuk mengharapkan imbalan dari masyarakat.

Berdasarkan uraian-uraian tersebut di atas, dapat ditarik simpulan bahwa kualitas pelayanan publik terhadap masyarakat baru mencapai kategori cukup, hal ini terbukti dari persentase rata-rata nilai tertinggi kualitas pelayanan publik tersebut hanya mencapai 63\%.

Untuk lebih memperjelas secara menyeluruh mengenai tingkat kualitas pelayanan publik, penulis uraikan sebagai berikut.

1. Tangibles (bukti langsung) $65 \%$ (Cukup)

2. Reliability (kehandalan) 67\% (Cukup)

3. Responsive (ketanggapan) 59\% (Cukup)

4. Asurance (jaminan) 61\% (Cukup)

5. Empathy $68 \%$ (Cukup)

Berdasarkan uraian di atas, nampak bahwa dari penerapan kelima indikator kualitas pelayanan publik baru mencapai nilai rata-rata $63 \%$ berarti baru mencapai predikat "Cukup". Jadi kualitas pelayanan publik pada pemerintah daerah Kabupaten Sumedang sudah cukup baik, hanya saja masih ada beberapa indikator yang belum dapat dilaksanakan secara maksimal.

Apabila menerapkan asas-asas motivasi yang baru mencapai nilai rata-rata 64\% dan tingkat kualitas pelayanan publik yang baru mencapai nilai rata-rata63\%, jelas bahwa terdapat hubungan yang sangat erat antara pelaksanaan motivasi dengan kualitas pelayanan publik. Dengan demikian, maka hipotesis yang penulis ajukan, yaitu :"Jika pelaksanaan motivasi oleh pemerintah daerah Kabupaten Sumedang berdasarkan asas-asas motivasi, maka kualitas pelayanan publik pada pemerintah daerah meningkat", telah teruji kebenarannya dan dapat diterima.

\section{SIMPULAN}

Bertitik tolak dari permasalahan mengenai pelaksanaan motivasi pemerintah daerah dalam meningkatkan kualitas pelayanan publik pada pemerintah daerah Kabupaten Sumedang, maka dapat ditarik suatu simpulan sebagai berikut.

1. Pemerintah daerah dalam pelaksanaan inovasi belum dapat melaksanakan motivasi secara optimal. Hal tersebut dapat terlihat dari penerapan asas-asas motivasi oleh pemerintah daerah dengan per oleh an rata-rata nilai tertinggi baru mencapai $64 \%$, sehingga apabila dihubungkan dengan standar persentase baru mencapai predikat"cukup". Jadi berdasarkan hal tersebut, dapat diambil simpulan bahwa ternyata pemerintah daerah dalam pelaksanaan motivasinya masih perlu meningkatkan penerapan asas-asas motivasi.

2. Pencapaian predikat "cukup" dalam penerapan asas-asas motivasi, akan berpengaruh terhadap proses pelaksanaan pekerjaan dari seluruh pegawai, dalam arti hasil kerjanya belum optimal. Hal ini terlihat dari pencapaian kualitas pelayanan publik yang baru mencapai rata-rata sebesar63\% dan bila dihubungkan dengan kriteria pengukuran analisis data baru mencapai predikat "cukup". 
3. Oleh karena itu, jelaslah bahwa terdapat hubungan yang sangat erat antara pelaksanaan motivasi dengan kualitas pelayanan publik. Dengan demikian, maka hipotesis yang penulis ajukan, yaitu: "Jika pelaksanaan inovasi pemerintah daerah dalam memotivasi aparatur oleh pemerintah daerah Kabupaten Sumedang berdasarkan asasasas motivasi, maka kualitas pelayanan publik pada pemerintah daerah meningkat", telah teruji kebenarannya dan dapat diterima.

\section{DAFTAR PUSTAKA}

Hasibuan, Malayu. S. P. 2006. Manajemen Dasar, Pengertian, dan Masalah. Jakarta: Bumi Aksara.

Kaloh, J.. 2007. Mencari Bentuk Otonomi Daerah. Jakarta: Rineka Cipta

Mangkunegara, Prabu, Anwar. 2009. Manajemen Sumber Daya Manusia Perusahaan. Bandung: PT. Remaja Rosdakarya

Manullang, 2006. Dasar-Dasar Manajemen. Yogyakarta: Gadjah Mada University Press

Moenir, H. A. S., 2008. Manajemen Pelayanan Umum di Indonesia. Jakarta: Bumi Aksara
Pasolong, Harbani. 2010. Kepemimpinan Birokrasi. Bandung: Alfabeta.

2011. Teori Administrasi Publik. Bandung: Alfabeta.

Sastrohadiwiryo, Siswanto. 2001. Manajemen Tenaga Kerja Indonesia. Jakarta: Bumi Aksara

Siagian, Sondang. 2004. Filsafat Administrasi. Jakarta: Bumi Aksara.

.2007. Fungsi-Fungsi Manajerial. Jakarta: Bumi Aksara

Soewarno, Handayaningrat. 1994. Pengantar Studi Administrasi dan Manajemen, Jakarta: Rineka Cipta

Sugiyono. 2010. Metode Penelitian Administrasi. Bandung: Alfabeta

Sutopo. 2003. Pelayanan Prima. Jakarta: Lembaga Administrasi Negara

Thoha, Miftah. 2001. Perilaku Organisasi Konsep Dasar dan Aplikasinya. Jakarta: Rajawali Pers

Wahjosumidjo. 1933. Kepemimpinan dan Motivasi. Jakarta: Balai Aksara

Laporan DUDI/Pakerin "Teori motivasi dan Aplikasinya" 